\title{
電気比抵抗法による深層混合処 QUALITY CONTROL ON THE 理土の圧縮強度に関する品質管 COMPRESSIVE STRENGTH OF 理 THE DEEP MIXING SOIL USING THE ELECTRICAL RESISTIVITY METHOD
}

\section{武智耕太郎—— $* 1$ 藤井 衛—— \\ 高 元浩—*3 新井 マウリシオ淳— * 4 \\ キーワード :}

電気比抵抗，圧縮強度，深層混合処理工法，品質管理

Keywords:

Electrical resistivity, Compressive strength, Deep mixing method, Quality control
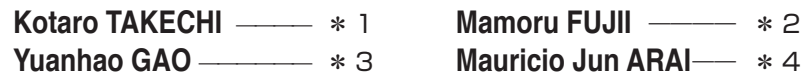

The controls of quality in the deep mixing stabilized soil methods are normally applied after the conclusion of construction, and depending on the results of tests, it is necessary to re-execution. In this study, it was examined the applicability of quality control methods on the compressive strength of deep mixing stabilized column by electrical resistivity method, comparing the resistivity ratio of 28th and third day age $\left(\rho_{28} / \rho_{3}\right)$ of field column with the laboratory tests. In addition, by resistivity of 28th day age $\left(\rho_{28}\right)$ of the column and the laboratory, is possible to estimate the compressive strength of improved column.

\section{1.はじめに}

深層混合処理工法における品質管理は、品質確認が難しく、通常 は、改良体をボーリングによって採取し、コア試験体の状態と材齢 28 日に扔ける圧縮強度から品質を評価している。これは非常に確実 な方法であるが、抜き取りによる手間や、抜き取りの本数の面で問 題がある。その上、ボーリングによるコア試験体は、ビットで削孔 して採取するため、慎重に作業を行ってもコア試験体を傷める可能 性がある。もし、現場において非破壊的検査ができれば、試験の効 率化や評価の信頼性の向上を図る事ができる。筆者らは、これまで 打設直後の改良体内に電極を挿入し、電気比抵抗（以後、比抵抗と 呼ぶ）の変化から現場において、改良体の均質性の評価を行ってき

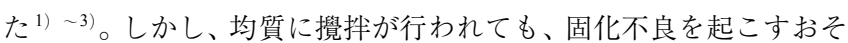
れもある。そこで筆者らは、現場改良体の材齢 28 日に打ける比抵抗 $\rho_{28}$ と材齢 3 日に扔ける比抵抗 $\rho_{3}$ との比 $\left(\rho_{28} / \rho_{3}\right)$ と室内配合土の $\rho_{28} / \rho_{3}$ との比較から品質を評価する方法や改良体の材齢 28 日にお ける圧縮強度を推定する方法を明らかにしたのでここに報告する。

\section{2. 本報告で用いる用語}

まず本報告で用いる主な用語の意味は次のとおりとする。

処理土：深層混合処理工法によって築造されるセメントと原地盤の 改良土であり、改良体を形作る材料

改良体：処理土により地中に形成される柱状の構造物

\section{3. 室内実験による適用性の検証}

比抵抗から圧縮強度を推定する試みは、モルタル ${ }^{4) 、 コ ン ク リ ー ~}$ ト5)の分野でも、これまでいくつかの方法が試みられてきた。モル
タルやコンクリートの骨材は土とみなすことができ、1 種の処理土 とも言える。したがって、比抵抗から圧縮強度を評価する価値は十 分にある。処理土の固化作用の中で、最も大きな働きをするのは、 セメント鉱物自身の水和反応である。まず、練混ぜ水とセメント鉱 物が反応し、セメント水和物が生成される。次に、そのセメント水 和物が土粒子間の空隙を緻密に埋めて発達し、強い結合状態となり、 圧縮強度が増大する ${ }^{6)}$ 。まず、土の比抵抗計測において、間隙水の 比抵抗が明らかであれば、比抵抗から土の間隙の大きさが推定でき る事に着目し ${ }^{7)}$ 、処理土が硬化していく時の比抵抗の変化と圧縮強 度の変化の関連性を明らかにする事を目的として室内実験を行った。

\section{1 実験概要}

表 1 に実験条件を、表 2 に使用した土の物理諸元を示す。試験体 （直径 $50 \mathrm{~mm}$ 、高さ $100 \mathrm{~mm}$ ） は、表 1 に示す様に、笠岡粘土と珪砂 7 号を質量比 5:5、6:4、7:3 で配合した土に、W/C を 60\%、80\%、 $90 \%$ 、固化材添加量を $200 \mathrm{~kg} / \mathrm{m}^{3} 、 300 \mathrm{~kg} / \mathrm{m}^{3} 、 400 \mathrm{~kg} / \mathrm{m}^{3}$ に変化させた セメントスラリーを混合攪拌して 27 配合の試験体を作製した。同じ 配合条件での試験体は、13 体作製し、12 体を一軸圧縮試験用、 1 体 を比抵抗測定用とした。比抵抗測定用の試験体には、電極と同径の 直径 $12 \mathrm{~mm}$ 、深さ $75 \mathrm{~mm}$ の試験孔をあらかじめ設けた。セメントは 普通ポルトランドセメント、練混ぜ水には水道水を用いた。一軸圧 縮試験（JIS A 1216:2009）は材齢 3、7、14、28 日とし、圧縮強度は 3 体の平均值から求めた。比抵抗は、写真 1 に示寸様に、電気伝導 率計の電極を試験孔に挿入して計測した。表 3 に使用した電気伝導 率計の仕様を示す。写真 2 は、比抵抗の測定状況である。計測は、 孔内に $0.1 \mathrm{~mol} / \mathrm{kg}$ の塩化カリウム溶液 (以下、 $\mathrm{KCL}$ 溶液と呼ぶ) を注入し、各配合で 1 体を材齢 1 2 8 日まで連続的に行った。

\footnotetext{
ジャパンホームシールド粕 修士（工学）

(テ 130-0026 東京都墨田区両国 2 丁目 10-14 両国シティコア 17F)

東海大学工学部建築学科 教授・工博

3 東海大学総合理工学研究科総合理工学専攻 院生・修士 (工学)

4 システム計測(㑣) 修士（工学）
}

Japan Home Shield Co., Ltd., M. Eng.

Prof., Dept. of Architecture and Building Engineering, Search Institute, Tokai Univ., Dr. Eng.

3 Graduate Student, Course of Science and Technology, School of Science and Technology, Tokai Univ., M. Eng.

System Measure Co., Ltd., M. Eng. 
表 1 実験条件

\begin{tabular}{|c|c|c|}
\hline $\begin{array}{c}\text { 固化材添加量 } \\
\mathrm{kg} / \mathrm{m}^{3}\end{array}$ & $\begin{array}{c}\mathrm{W} / \mathrm{C} \\
\%\end{array}$ & $\begin{array}{c}\text { 土の種類 } \\
\text { 笠岡粘土 : 珪砂7号 }\end{array}$ \\
\hline 200 & 60 & $5: 5$ \\
\hline 300 & 80 & $6: 4$ \\
\hline 400 & 90 & $7: 3$ \\
\hline
\end{tabular}

表 2 使用した土の物理諸元

\begin{tabular}{|c|c|c|c|c|c|c|c|}
\hline 土の種類 & 土粒子 & $\begin{array}{l}\text { 自然 } \\
\end{array}$ & 液性 & 塑性 & \multicolumn{3}{|c|}{ 粒度特性（\%） } \\
\hline 笠岡粘土：珪砂7号 & $\mathrm{g} / \mathrm{cm}^{3}$ & $\%$ & $\%$ & $\%$ & 砂分 & シルト分 & 粘土分 \\
\hline $5: 5$ & 2.75 & 23.6 & 35.8 & 14.0 & 45.2 & 26.1 & 28.7 \\
\hline $6: 4$ & 2.60 & 23.3 & 41.6 & 16.1 & 36.7 & 30.2 & 33.1 \\
\hline $7: 3$ & 2.76 & 31.6 & 46.5 & 19.5 & 30.3 & 36.5 & 33.2 \\
\hline
\end{tabular}

表 3 電気伝導率計の仕様

\begin{tabular}{|c|c|}
\hline 型番 & $\mathrm{CT}-27112 \mathrm{~B}$ \\
\hline 比抵抗測定範囲 & $0.5 \Omega \cdot \mathrm{m} \sim 10 \mathrm{~K} \Omega \cdot \mathrm{m}$ \\
\hline 使用温度 & $0 \sim 80^{\circ} \mathrm{C}$ \\
\hline 使用湿度 & $<95 \mathrm{RH} \%$ \\
\hline
\end{tabular}

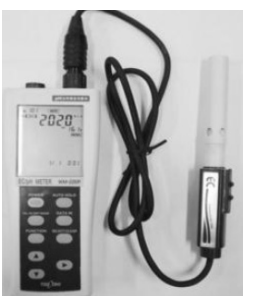

写真 1 電気伝導率計

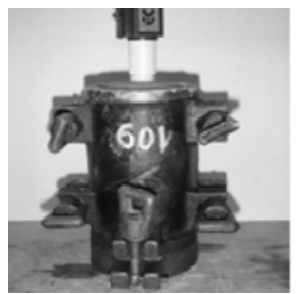

(a) 全景

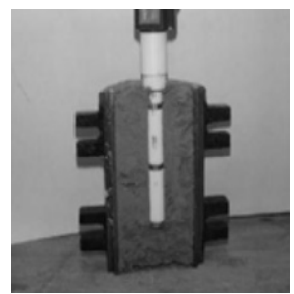

(b) 断面
写真 2 測定状況

\section{2 実験結果と考察}

図 1 は、圧縮強度と比抵抗の関係を示したものである。図 1 に示 すように、すべての試験体で、圧縮強度と比抵抗との間に相関関係 が認められた。この要因として、含水比の変化と間隙の変化の $2 つ$ の要因が考えられる。図 2 は含水比の材齢による变化を示したもの であるが、いずれも材齢による大きな違いは見られなかった。した がって、比抵抗の材齢による変化は含水比の影響を受けているとは 考えられない。また、写真 3 は処理土の組織の材齢による変化を、 電子顕微鏡で観察した状況である。これより、材齢が進むにつれて、 組織が緻密になって行く様子が分かる。このことから、溶液の比抵 抗が一定の場合、処理土の比抵抗は、間隙の変化を示していると考 えられる。したがって、各試験体の比抵抗の増加に伴う圧縮強度の 変化量と材齢 28 日の比抵抗から、（1）式の様な圧縮強度予測式が表 される。ここでは測定精度を考慮し、(1)式の a 及び b は材齢 3、7、 14 日の 3 点から求めた。

$\mathrm{q}_{\mathrm{u} 28 \mathrm{p} 1}=\mathrm{a} \cdot \rho_{28}+\mathrm{b}$

$\mathrm{qu}_{28 \mathrm{p} 1}$ :推定材齢 28 日の圧縮強度 $\rho 28$ : 材齢 28 日の比抵抗

$\mathrm{a}:\left(\sum \rho_{\mathrm{i}} \cdot \mathrm{qu}_{\mathrm{i}}-\mathrm{n} \cdot \rho_{\mathrm{i}} \cdot \mathrm{qu}_{\mathrm{i}}\right) /\left(\sum \rho_{\mathrm{i}}^{2}-\mathrm{n} \rho_{\mathrm{i}}^{2}\right)$

$\mathrm{n}$ : 測点数

$\mathrm{b}: \mathrm{qu}_{\mathrm{i}}-\mathrm{a} \rho_{\mathrm{i}}$

$\mathrm{qu}_{\mathrm{i}}$ : 同一配合の圧縮強度 $\rho_{\mathrm{i}}$ : 同一配合の比抵抗
（1）式より推定值 $\mathrm{q}_{\mathrm{u} 28 \mathrm{p} 1}$ を求め、実測值 $\mathrm{q}_{\mathrm{u} 28}$ と比較すると、図 3 に示すように、両者は概ね一致した。以上より、圧縮強度と比抵抗 の関係から、材齢 28 日の圧縮強度の推定が可能となる。これを現場 で使用する事を考えた場合、事前に室内配合土で(1)式の a、b を算 出し、この結果と現場改良体の材齢 28 日における比抵抗から圧縮強 度が求まることになる。しかし、この方法で強度を推定するには、 現場改良体から求め得る $a 、 b$ と室内配合土で求めた $a 、 b$ が近い值 であるという条件が必要となる。両者の材料は同じであるため、固 化不良を起こしていなければ $\mathrm{a} 、 \mathrm{~b}$ は近い值になるものと考えられる。

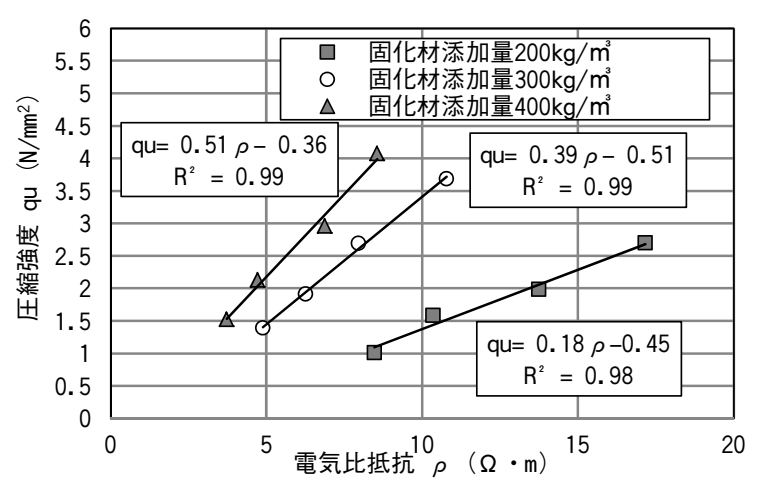

図 1 圧縮強度と電気比抵抗の関係 （笠岡粘土：珪砂 7 号 $=5: 5 、 W / C=60 \%$ )

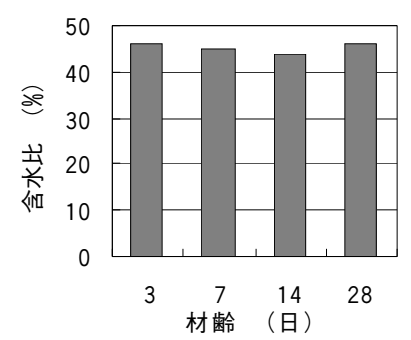

図 2 含水比と材齢の関係の例

(笠岡粘土 : 珪砂 7 号 $=6: 4 、 W / C=60 \%$ 、固化材添加量 $400 \mathrm{~kg} / \mathrm{m}^{3}$ )

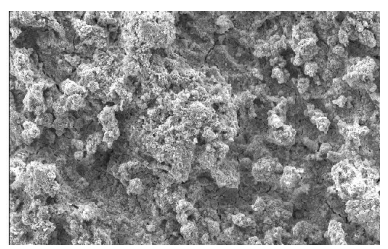

（a）材齢 3 日

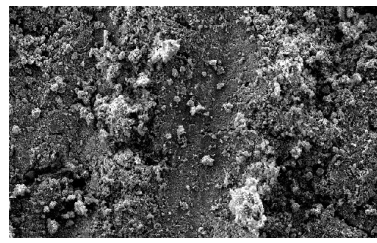

(c) 材齢 14 日

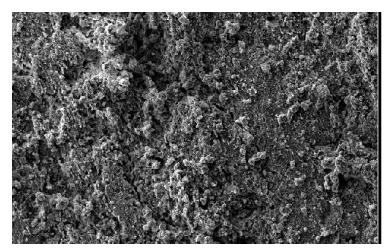

（b）材齢 7 日

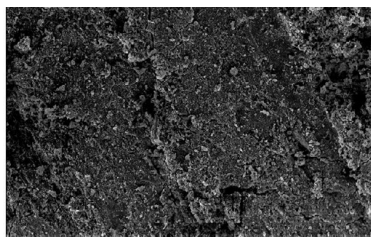

(d) 材齢 28 日
写真 3 材龄経過に伴う試験体の組織の変化の例（倍率 500 倍） （笠岡粘土：珪砂 7 号 $=6: 4 、 W / C=60 \%$ 、固化材添加量 $400 \mathrm{~kg} / \mathrm{m}^{3}$ ) 


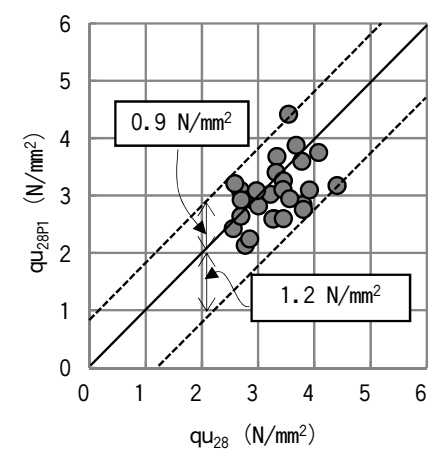

図 3 推定值 $\mathrm{q}_{\mathrm{u} 28 \mathrm{p} 1}$ と実測值 $\mathrm{q}_{\mathrm{u} 28}$ の関係

\section{4. 固化不良の改良体について}

3.2 で示した様に、比抵抗が間隙の変化を反映する事により、圧 縮強度の予測が可能であるが、室内配合土から求めた值を用いて (1) 式から現場の改良体の強度を推定しょうとする場合、現場の改良体 が固化不良を起こしていないという条件が必要となる。ここでは、 改良体の不良杭を例に、比抵抗による固化不良の評価方法を示寸。 表 4 は、既往の文献 ${ }^{8)}$ に示されている改良体の不良杭の例に、筆者 が加筆したものである。改良体の不良杭には、1〜4のパターンが考 えられる。1 と 2 は、攪找具合のばらつきによる不良であり、3 と 4 は、未固化による不良である。 3 と 4 は、未固化のため、水和反応 による間隙の収縮が少ない。したがって、正常に固化した試験体と 比抵抗の材齢による変化量を比較する事で品質の評価が可能となる。 1 と 2 は、未固化と固化部分が存在するため、間隙の収縮具合に、 ばらつきが生じる。そのため、同一土層中の比抵抗のばらつきを確 認する事で、判断が可能と考えられる。比抵抗の材齢による変化量 は、材齢 3 日と材齢 28 日の比抵抗を割った值(以下、 $\rho_{28} / \rho_{3}$ とする) で、評価することとした。既往の文献においてセメント水和物の生 成が、材齢 3 日から増大し、材齢 28 日までに収まることが報告され ていることから ${ }^{9)} 、 \rho_{28} / \rho_{3}$ は水和反応全体の間隙の変化を表す值で あるため、反応速度の異なる現場改良体と室内配合土の值を比較し ても問題がないと考えられる。すなわち、室内配合土で正常に固化 した際の $\rho_{28} / \rho_{3}$ を求め、現場改良体との比較と、同一土層における $\rho_{28} / \rho_{3}$ のばらつき具合を確認する事により、現場改良体が固化して いるかどうかを評価する事が可能となる。

\section{5. 比抵抗による品質検査法の提案}

比抵抗による圧縮強度に関する品質検査方法の流れを図 4 に示す。 比抵抗による圧縮強度に関する品質検査は、強度予測式の適用条件 である現場の改良体が固化不良を起こしていない事を(1)、(2)の $\rho_{28} /$ $\rho_{3}$ の大きさとそのばらつきから評価し、適用が可能である場合(3)で、 圧縮強度の推定式を適用し、この強度と設計基準強度の比較をし、 改良体の連続性と強度の大きさの両面を評価する。

\section{1 試験方法}

図 5 に、計測状況概要図を示す。また、計測の状況を写真 4 に示 す。計測は、未固化状態の改良体に比抵抗プローブと同径の鉄製の 棒を挿入し、翌日その棒を抜き取り作製した試験孔に、比抵抗プロ ーブを圧入して行った。計測の際には、比抵抗プローブと改良体の 間を $0.1 \mathrm{~mol} / \mathrm{kg} \mathrm{KCL}$ 溶液を注入して間隙を満たした。測定間隔は、
表 4 改良体の不良杭の例 8) に加筆・变更

\begin{tabular}{|c|c|c|c|c|}
\hline No & 1 & 2 & 3 & 4 \\
\hline $\begin{array}{l}\text { 改 } \\
\text { 良 } \\
\text { 体 } \\
\text { の } \\
\text { 固 }\end{array}$ & 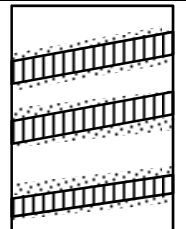 & 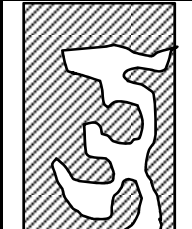 & ש/ & $\mathbb{W}$ \\
\hline 柷 & $\begin{array}{l}\text { 改良体中で固化 } \\
\text { 部分が筋状に形 } \\
\text { 成される }\end{array}$ & $\begin{array}{l}\text { 未処理土と処理 } \\
\text { 土が混り合う塊 } \\
\text { 状改良体となる }\end{array}$ & $\begin{array}{l}\text { 改良杭の外周部 } \\
\text { のみ改良され塊 } \\
\text { 中心部は改良さ } \\
\text { れい }\end{array}$ & $\begin{array}{l}\text { 特定の深度で改 } \\
\text { 良体の強度が発 } \\
\text { 現していない }\end{array}$ \\
\hline \begin{tabular}{|l} 
原 \\
因
\end{tabular} & $\begin{array}{l}\text { 攪拌回数が少な } \\
\text { いと、攪拌翼の } \\
\text { 軌跡に沿ってス } \\
\text { ラリーが集中す } \\
\text { る。 }\end{array}$ & $\begin{array}{l}\text { 1) 攪拌翼の間隔 } \\
\text { が狭すぎると改 } \\
\text { 良対称土が処理 } \\
\text { 機の回転軸と共 } \\
\text { 回りし、混練り } \\
\text { がなされない。 } \\
\text { 2) スラリーの吐 } \\
\text { 出が不規則 } \\
\text { 3) 攪拌回数が少 } \\
\text { ない。 }\end{array}$ & $\begin{array}{l}\text { 覺拌翼の回転速 } \\
\text { 度が速すぎた } \\
\text { り、スラリーが } \\
\text { 改良杭の外周部 } \\
\text { に多く存在する } \\
\text { という偏りが出 } \\
\text { て、中心部が固 } \\
\text { 化されていない } \\
\text { 改良杭となる。 }\end{array}$ & $\begin{array}{l}\text { 固化し難い土層 } \\
\text { がある。固化材 } \\
\text { 種類、添加量の } \\
\text { 選定不備 }\end{array}$ \\
\hline
\end{tabular}

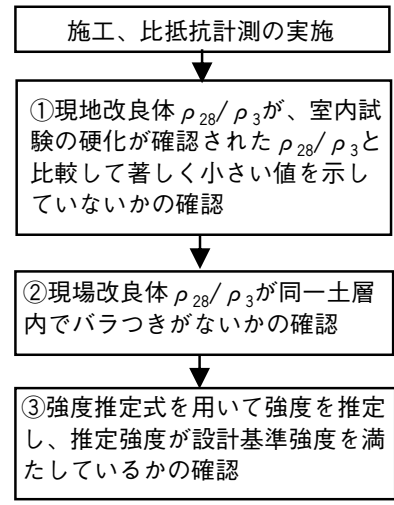

図 4 比抵抗による圧縮強度に関 する品質検査方法の流れ

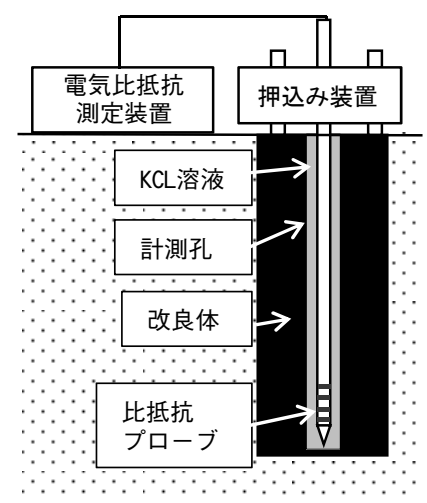

図 5 計測状況概要図
$25 \mathrm{~cm}$ である。比抵抗の測定は、材齢 1〜7、10、14、21、28 日に行 った。また、現場にて $1 \mathrm{~m}$ 間隔で採取した土を用いて、改良体と同 配合の室内配合土を作製し、一軸圧縮試験（材齢 3、7、28日）、比 抵抗計測試験（材齢 1 28 日、計測方法は 3.1 によ）を行った。 また、推定圧縮強度の妥当性の検証と改良体が固化しているかどう かを確認するために、ボーリングにより採取したコア試験体の一軸 圧縮試験（材齢 28 日）を行った。比抵抗プローブの電極配置は Wenner 式 4 電極法を採用した。比抵抗プローブの電極配置図を図 6 比抵抗測定器の仕様を表 5、比抵抗プローブを写真 5 に示す。また 比抵抗は、温度依存性が認められるため ${ }^{10)}$ 、測定值の温度補正が必 要となる。ここでは、基準温度を $25^{\circ} \mathrm{C}$ と、温度補正は (2) 式 ${ }^{10)}$ を用いて行った。

$\rho_{25}=\rho_{\mathrm{t}} \cdot\{1+0.02 \times(\mathrm{t}-25)\}$

$\rho_{25}: 25^{\circ} \mathrm{C}$ の電気比抵抗 $(\Omega \cdot \mathrm{m})$

$\rho_{\mathrm{t}}: \mathrm{t}^{\circ} \mathrm{C}$ の電気比抵抗 $(\Omega \cdot \mathrm{m}) \quad \mathrm{t}:$ 温度 $\left({ }^{\circ} \mathrm{C}\right)$ 


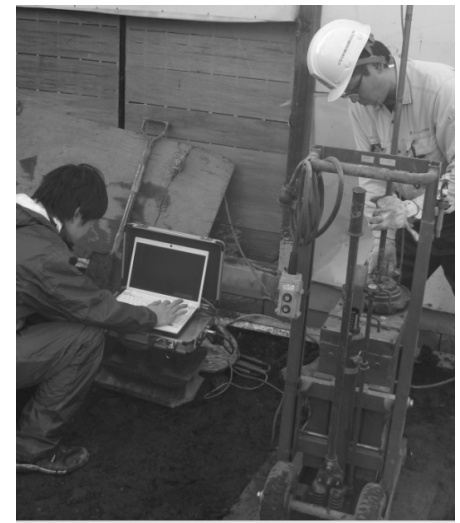

写真 4 計測状況

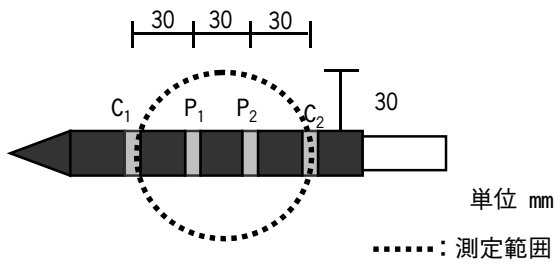

図 6 比抵抗プローブの電極配置

表 5 比抵抗測定器の仕様

\begin{tabular}{|c|c|}
\hline 測定切替レンジ & $0.1 \mathrm{~mA} \sim 20 \mathrm{~mA}$ \\
\hline 比抵抗測定範囲 & $0 \Omega \cdot \mathrm{m} \sim 20 \mathrm{k} \Omega \cdot \mathrm{m}$ \\
\hline 電源電圧 & $\mathrm{DC} 100 \mathrm{~V}$ \\
\hline 使用温度 & $0^{\circ} \mathrm{C} \sim 50^{\circ} \mathrm{C}$ \\
\hline 使用湿度 & $<80 \mathrm{RH} \%$ \\
\hline
\end{tabular}

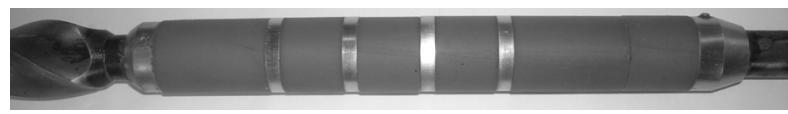

写真 5 比抵抗プローブ

\section{6. 改良体の施工不備による固化不良の評価}

提案した品質検査方法の流れに従い、改良体の固化不良の状況を 確認し、品質検查方法の妥当性を検証した例を示す。

\section{1 地盤と改良体の概要}

地盤と改良体の概要を図 7 に、表 6 に土の物理緒元を示す。土層 構成は上部から、盛土、粘土、シルトなっている。改良長は $5.0 \mathrm{~m}$ 、 改良体の径は $\phi 600 \mathrm{~mm}$ 、配合は $\mathrm{W} / \mathrm{C}=60 \%$ 、固化剂添加量 $300 \mathrm{~kg} / \mathrm{m}^{3}$ とした。なお、試験対象区間は、表層から $3.25 \mathrm{~m}$ までである。室内 配合土と現場改良体の比較は層区分を元に $0 \sim 0.75 \mathrm{~m}$ は $0.5 \mathrm{~m} 、 1 \mathrm{~m} \sim$ $1.75 \mathrm{~m}$ は $1.5 \mathrm{~m} 、 2 \mathrm{~m} \sim 2.75 \mathrm{~m}$ は $2.5 \mathrm{~m} 、 3 \mathrm{~m} \sim 3.25 \mathrm{~m}$ は $3.5 \mathrm{~m}$ の深度で検 討を行うこととした。図 8 に施工概要図を示す。固化材スラリーの 吐出方法は、通常貫入時もしくは引抜時に行うが 6)、本地盤では、 貫入時と引抜時の両方で注入する方法で行った。この方法は、既往 の論文 ${ }^{11}$ において攪拌回数の違いから、改良具合にばらつきが生じ る事が示されており、攪拌不良になる事を想定し、実験用に作製し た改良体である。

\section{2 室内配合土、現場改良体の計測結果の検討}

図 9 は室内配合土の圧縮強度試験結果であり、図 10 は室内配合土 の各深度における $\rho_{28} / \rho_{3}$ を示したものである。図 9 より、室内配合 土は材齢が進むに従って圧縮強度が、増加する傾向を示している。 図 10 より、室内配合土の $\rho_{28} / \rho_{3}$ の基準值は、0 0.75m は 2.1、1 $1.75 \mathrm{~m}$ は 2.2、2 2.75m は 2.8、3〜3.25m は 2.7 となり、現場改良体 で、この基準值と同等であれば、一定以上の圧縮強度が得られてい るものと考えられる。図 11 は、現場改良体の各深度における $\rho_{28} / \rho_{3}$ を示したものである。現場改良体の $\rho_{28} / \rho_{3}$ は、すべての深度で基準 值の $1 / 2$ 程度であった。これは、全長で十分な圧縮強度が、発揮され ていない可能性があることを示している。このことを検証するため に、コア試験体の圧縮強度を調べた。

図 12 は、コア試験体の材齢 28 日に抢ける圧縮強度試験結果を示 したものである。コア試験体の圧縮強度は、室内配合土の結果と比 較して、やはり十分な圧縮強度が得られていない。またコア試験体 を観察すると、全体として欠損が多く、攪拌が不十分な状態であっ た。コア試験体の状況を写真 6 に示す。以上より、圧縮強度が発揮 されていない現場改良体では、 $\rho_{28} / \rho_{3}$ が、室内配合土の值よりも低 い值を示すので、両者の $\rho_{28} / \rho_{3}$ の大きさから固化不良の状況を捉え る事ができると分かった。

表 6 土の物理諸元

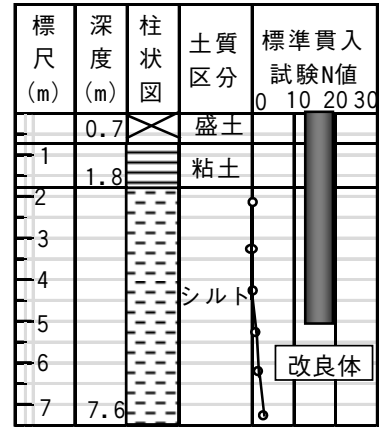

\begin{tabular}{|c|c|c|c|c|c|}
\hline \multicolumn{2}{|c|}{ 深度 (m) } & 0.50 & 1.50 & 2.50 & 3.50 \\
\hline \multicolumn{2}{|c|}{ 土粒子の密度 $\left(\mathrm{g} / \mathrm{cm}^{3}\right)$} & 2.7 & 2.7 & 2.7 & 2.7 \\
\hline 自然含水上 & $=W_{n}(\%)$ & 28.4 & 28.3 & 34.3 & 36.1 \\
\hline 液性限界 & WL (\%) & 74.8 & 67.0 & 57.0 & 64.1 \\
\hline 塑性限界 & WP(\%) & 53.6 & 38.9 & 35.4 & 41.0 \\
\hline $\begin{array}{l}\text { 粒 } \\
\text { 度 }\end{array}$ & 粘土 & 30.9 & 1.6 & 0.4 & 1.6 \\
\hline 布 & シルト & 34.5 & 62.3 & 74.6 & 71.3 \\
\hline$\%$ & 砂 & 19.5 & 36.1 & 25.0 & 27.1 \\
\hline
\end{tabular}

図 7 地盤と改良体の概要

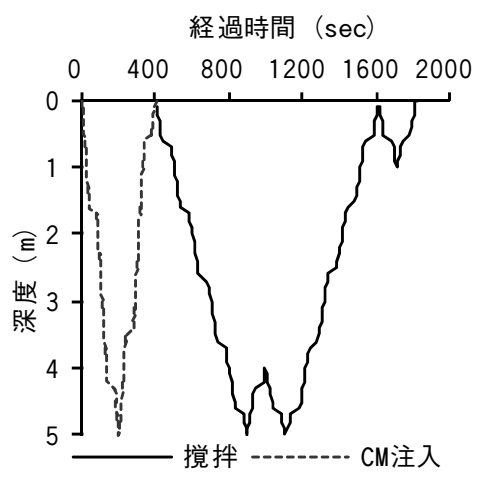

図 8 施工概要図 


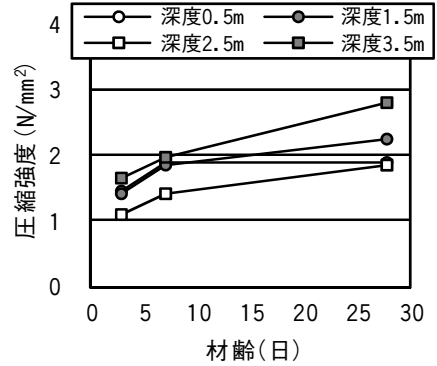

図 9 室内配合土の圧縮強度 試験結果

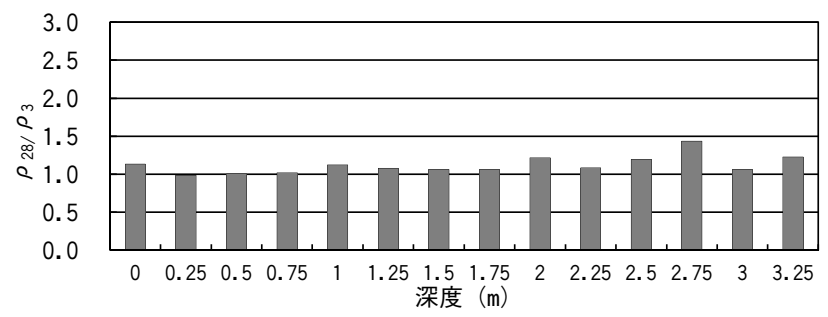

図 11 現場改良体の各深度における $\rho_{28} / \rho_{3}$

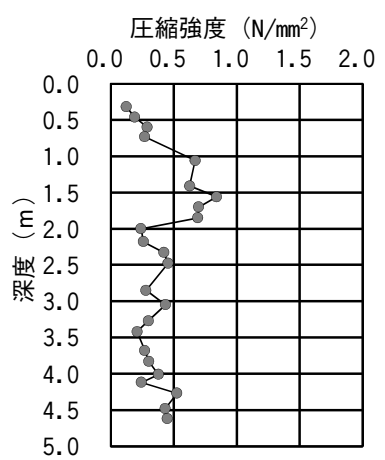

図 12 コア試験体の材齢 28 日における圧縮強度試験結果

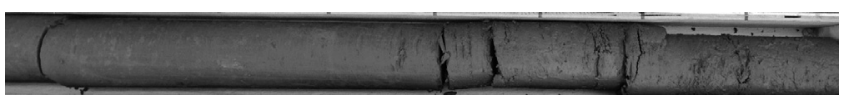

写真 6 コア試験体の状況

\section{7. 改良体の圧縮強度の推定}

提案した品質検查方法の流れに従い、改良体の推定圧縮強度を確 認し、品質検查方法の妥当性を検証した例を示す。

\section{1 地盤と改良体の概要}

地盤と改良体の概要を図 13 に、表 7 に土の物理緒元を示す。土 層構成は、上部から盛土、黒ボク、ロームとなっている。改良長は $4 \mathrm{~m}$ 、改良体の径は $\phi 600 \mathrm{~mm}$ 、配合は $\mathrm{W} / \mathrm{C}=60 \%$ 、固化剂添加量 $300 \mathrm{~kg} / \mathrm{m}^{3}$ とした。室内配合土と現場改良体の比較は層区分を元に 0 $\sim 1.0 \mathrm{~m}$ は $0.5 \mathrm{~m} 、 1.25 \mathrm{~m} \sim 2 \mathrm{~m}$ は $1.5 \mathrm{~m} 、 2.25 \mathrm{~m} \sim 2.75 \mathrm{~m}$ は $2.5 \mathrm{~m} 、 3 \mathrm{~m} \sim$ $3.75 \mathrm{~m}$ は $3.5 \mathrm{~m}$ の深度で検討を行うこととした。図 14 に施工概要図 を示す。

\section{2 室内配合土、現場改良体の計測結果の検討}

図 15 に室内配合土の圧縮強度試験結果を、図 16 に室内配合土の 各深度における $\rho_{28} / \rho_{3}$ を示す。図 15 より、室内配合土は、材齢が進 むに従って、圧縮強度が増加する傾向を示している。図 16 より、。 ${ }_{28} / \rho_{3}$ の基準值は、0〜1m は 1.4、1.25〜2m は 1.2、2.25～2.75m は 1.1、 3〜3.75m は 0.8 となり、現場改良体がこの值と同等な值を示してい ると、一定以上の圧縮強度を得られているものと評価できることに なる。図 17 は、現場改良体の各深度における $\rho_{28} / \rho_{3}$ を示したもので ある。現場改良体の $\rho_{28} / \rho_{3}$ は、基準值との差が最大で 0.2 であり、 基準值とほほ同等な值を示している。これは、十分な圧縮強度が発 揮されている可能性がある。このことを検証するためにコア試験体 の圧縮強度試験を行った。

図 18 には、実測值としてコア試験体の材齢 28 日における圧縮強 度試験結果を示している。各深度で、室内配合土の結果に、近い圧 縮強度が得られている。したがって、現場改良体の $\rho_{28} / \rho_{3}$ と室内配 合土の $\rho_{28} / \rho_{3}$ より、改良体が固化しているかどうかを評価できる。 図 18 に（1）式より求めた推定圧縮強度 $\mathrm{qu}_{28 \mathrm{p} 1}$ と深度の関係を、図 19 に推定圧縮強度 $\mathrm{qu}_{28 \mathrm{p} 1}$ と実測値 $\mathrm{qu}_{28}$ の関係を示す。(1) 式の $\mathrm{a} 、 \mathrm{~b}$ の算出には、室内配合土の材齢 3、7、28 日のデー夕を用い、 $\rho_{28}$ には現場改良体の值を適用した。なお、表層 $0 \mathrm{~m}$ は、不均質である ため、検討から除外している。図 18、19より、推定值 $\mathrm{qu}_{28 \mathrm{p} 1}$ は、実 測值 $\mathrm{qu}_{28}$ と良く一致し非常に高い相関性を示す。したがって、室内 配合土の圧縮強度、比抵抗と現場改良体の $\rho_{28}$ を計測することで、 改良体の材齢 28 日の圧縮強度を推定出来る事が分かった。

表 7 土の物理諸元

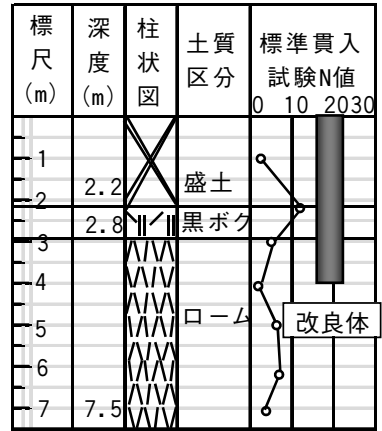

\begin{tabular}{|c|c|c|c|c|c|}
\hline \multicolumn{2}{|c|}{ 深度 (m) } & 0.5 & 1.5 & 2.5 & 3.5 \\
\hline 土粒子の密 & 度 $\left(\mathrm{g} / \mathrm{cm}^{3}\right.$ & 2.6 & 2.8 & 2.7 & 2.7 \\
\hline 自然含水上 & t $W_{n}(\%)$ & 64.9 & 58.6 & 87.7 & 130 \\
\hline 液性限界 & WL (\%) & 102 & 111 & 125 & 159 \\
\hline 塑性限界 & WP(\%) & 76.6 & 74.5 & 84.0 & 111 \\
\hline & 粘土 & 14.8 & 26.7 & 14.1 & 42.6 \\
\hline 布 & シルト & 65.7 & 40.6 & 41.4 & 43.6 \\
\hline$\%$ & 砂 & 23.2 & 32.7 & 44.5 & 13.9 \\
\hline
\end{tabular}

図 13 地盤と改良体の概要

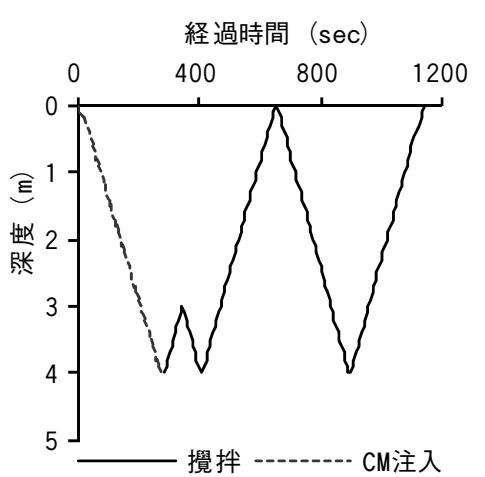

図 14 施工概要図 


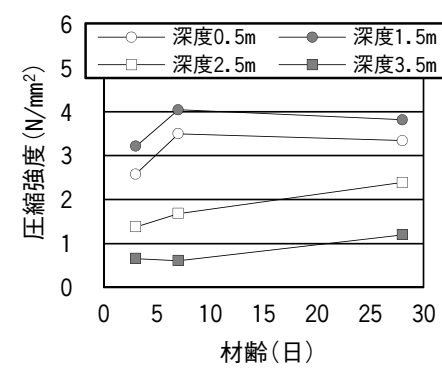

図 15 室内配合土の圧縮強度 試験結果

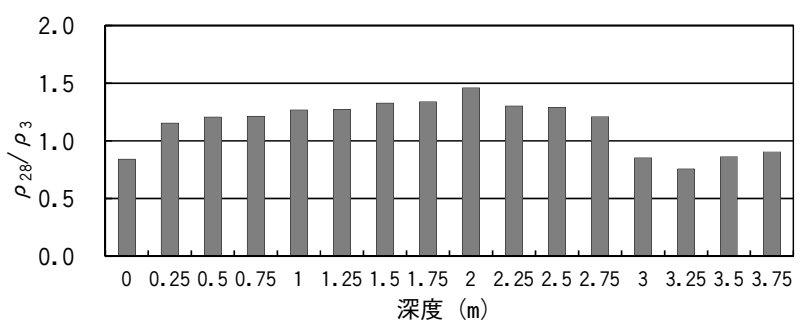

図 17 現場改良体の各深度における $\rho_{28} / \rho_{3}$

圧縮強度 $\left(\mathrm{N} / \mathrm{mm}^{2}\right)$

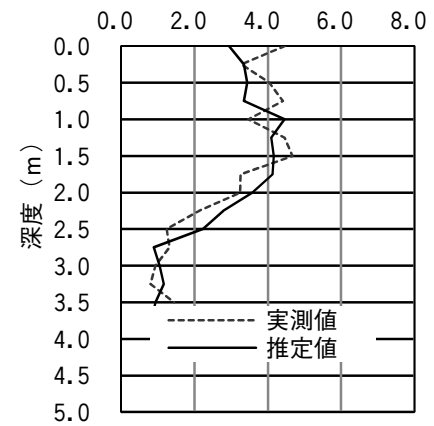

図 18 推定圧縮強度 $\mathrm{qu}_{28 \mathrm{p} 1}$ と 深度の関係

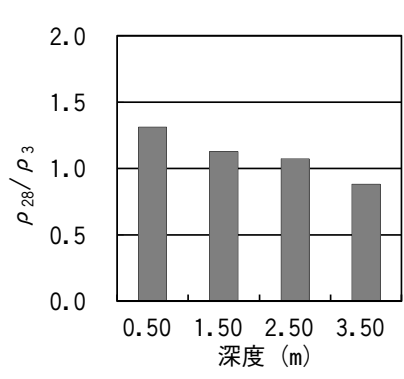

図 16 室内配合土の各深度

における $\rho_{28} / \rho_{3}$
実験、現場実験による測定データを蓄積し、弱材齢の比抵抗から材 齢 28 日の圧縮強度を推定する式など、時間費用を考慮した推定式を 検討していく予定である。

\section{謝辞}

本研究は、平成 $22 \sim 24$ 年度 住宅 ·関連先導技術開発助成事業の 補助金により実施したものである。ここに深く感謝致します。

\section{【参考文献】}

1）田村昌仁、藤井衛、青木功、小川能克、武内義夫、日比野信一、神保俊次、 都築充雄、加藤千博、津田佳昭:電気比抵抗による改良体の品質評価に関する 現場実験、日本建築学会構造系論文集、第 531 号、pp.95 99、2000.5

2) 藤井衛、川村政史、田村昌仁、渡辺一弘、溝口栄二郎: 深層混合処理工法 による改良体を対象とした品質確認・推定手法、材料、Vol.53、No.1、pp.9〜 12、2004.1

3）藤井衛、新井マウリシオ淳、久保豊、伊集院博、千葉原敦：電気比抵抗測 定による深層混合処理工法の品質管理、日本建築学会大会学術講演梗概集 B-1、2010、pp.475 476、2010.7

4）小野博宣、加藤聡、大岸佐吉：セメントモルタルの電気比抵抗に及ぼす測 定条件の影響、セメントコンクリート論文集、No.46、pp.344～399、1992 5）藤原浩巳、丸岡正知、岡村洋一、林志翔 : 比抵抗法を用いた非破壞的コン クリート压縮強度推定方法に関する研究、セメントコンクリート論文集、 No.55、251 256、2002

6)財団法人土木研究センター：陸上工事に㧍ける深層混合処理工法設計・施 エマニュアル、pp.20 143、2004.3

7) 藤井衛: 比抵抗計測による土の毛細管性状の調查、土質工学会論文報告集、 Vol.21、No.1、pp.131〜138、1981.1

8) 社団法人土質工学会: 地盤改良のトラブルの要因とその対策、pp.184〜185、 1995.9

9)川村満紀、枷場重正、杉浦精治、中野寿：ソイルセメントに抢ける粘土鉱 物とセメントの相互作用の役割、土木学会論文報告集、vol.169、pp.31 43、 1969.9

10）高橋宣之、河内邦夫、矢部和夫、中村隆俊、後藤典俊：携帯型電導度測 定機器の開発と湿原環境調査への適用、室蘭工業大学紀要、vol.54、pp.137〜 145、2004.11

11）芳沢秀明、奥村良介、細谷芳巳、須見光二、山田哲司:改良土の品質に影 響を与える施工要因について、地盤工学会 セメント系安定処理土に関する シンポジウム発表論文集、pp76〜95、1996

12)一般財団法人日本建築センター:改訂版建築物のための改良地盤の設計及 び品質管理指針、pp. $238 \sim 255 、 2002.11$

[2013 年 6 月 19 日原稿受理 2013 年 8 月 12 日採用決定］

1）現場改良体にて、室内配合土の比抵抗と圧縮強度、現場改良体 の $\rho_{28}$ から材齢 28 日の圧縮強度を推定する事が出来る。

2) 室内配合土で正常に固化した際の $\rho_{28} / \rho_{3}$ と現場改良体の $\rho_{28} /$ $\rho_{3}$ を比較する事により、現場改良体が固化しているかどうかを 評価する事が出来る。

本手法と既往の論文 1) 3) で示した打設直後の調查を組み合わせ

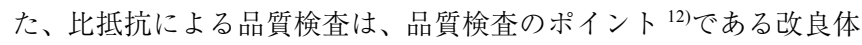
の連続性と圧縮強度を把握する事が出来、従来のコア採取による品 質管理に加える事により、非常に効率よく、かつ適切な品質検査に なり得る。今後は、様々な土質及び固化材に対応できるように室内 